\title{
Sustainability of a Social Business: A Case Study on Grameen Danone Foods Limited
}

\author{
Nur Nahar Yasmin \\ Lecturer, Department of Management, University of Dhaka, Dhaka-1000, BANGLADESH \\ E-mail for correspondence: nny_mgt_du@hotmail.com
}

DOI: https://doi.org/10.18034/abr.v6i3.42

\begin{abstract}
Achieving sustainability in the context of economic, social and environmental aspects has been one of the main focuses of modern times. The aim is to create the world that will facilitate the upcoming generations to lead a safe and sound life. Social business is a relatively new concept that assists in the creation of such a sustainable world by promoting and following the notion of "no-loss, no-dividend" business instead of conventional profit-maximizing business. The purpose of this paper is to show whether a social business can become a sustainable business and achieve the sustainable development goals set by United Nations. To scrutinize this theory of social business for sustainable development the author has selected Grameen-Danone Foods Limited (GDFL) as a case study. The endeavor of this paper is to elaborate the relationship between social business and sustainable development, describe GDFL as a social business and analyze the success (or failure) of GDFL as a sustainable social business. Finally, it tries to showcase a comparison of few of the sustainable development goals and the outcomes of the analysis of the business and social goals of GDFL.
\end{abstract}

\section{JEL Classifications: M 10}

Keywords: Sustainable development, social business, Grameen Danone Foods Limited, Shakti Doi, poverty, malnutrition

\section{INTRODUCTION}

Sustainable development is a relatively new concept. Several authors have talked about it as a process of survival of the upcoming generation. But recently the idea has been brought to the limelight by the United Nations through their 17 sustainable development goals and 169 targets. Sustainable development is highly related to the process of social business as both talk about poverty elimination, innovative idea generation and fostering innovation, elimination of inequality and thus over all social development. Several scholars like Humberg and Kleemann (2014), Yunus (2007) have linked social business with sustainable development. In an interview regarding social business Nobel Peace Prize winner, Dr. Yunus has said that "over the past three decades there has been a feeling of discomfort about development programs based on handouts, charity and safety nets. It is no longer an issue of debate: development without sustainability cannot be meaningful nor have the required impact" (Park 2015, p. 27).
Social business is the brain child of Dr. Yunus which he links up with sustainable development. He said "we are to focus on the three 'zeros.' Creating the world without poverty, without unemployment, and the third 'zero' is zero net carbon emission. Thus, if we can achieve those three 'zeros' by 2050, we have switched into a new civilization where there is no poverty, no unemployment, and no environmental degradation. And in the meantime, we have to change the nature of the economy that we have built." (Park 2015, p. 28). The government of Bangladesh received highly appreciations as they had achieved the Millennium Development Goals two and a half years prior the deadline. So they have taken active steps to attain the SDGs before 2030, and social business will be an approach to achieve these goals.

According to Yunus (2007), his 30 years long experience of working with social organizations whose purpose is to alleviate poverty has driven him to the development of the innovative idea of "Social business." This concept is not only accepted but also highly appreciated all around the 
world. Khan (2015) explained that several countries such as Cambodia, Philippines, Nepal, India, Haiti, Colombia, Uganda, Brazil, Albania are using social business as a weapon to remove poverty and create a better life for the poor thus achieving the goals of sustainable development. Grameen-Danone Foods Limited (GDFL) is known to be the first joint venture social business with the aim to eliminate malnutrition of children and create innovative employment opportunities of a locality. Thus in this study the focus will be on the work process of GDFL and how sustainable they are as a social business and regarding sustainable development goals by United Nations.

\section{LITERATURE REVIEW}

The concept of "business" generally revolves around profit generation, or we can say profit maximization. A firm or business, when, involved in the trade of goods, services or both for profit generation, is the situation we presume as a conventional business venture (Sullivan and Steven, 2003). The process of capitalism has enabled us with the free market economy, but it has at the same time snitched the obligation of poverty elimination. Social inequality is the main reason for poverty as they disregard morals and public safety for the hunt of profit (Sowell, 2003). As the deviation of social classes got larger day by day, the realization for sustainability and equity become more prominent.

For sustainable development, Butlin (1989) said, "Which meets the needs and aspirations of the present without compromising the ability of future generations to meet their own needs." The improper and reckless use of the finite natural, financial and human resource will only affect our future generation in a negative way. Thus working with "integrity, stability and beauty" of natural resources (Leopold, 1949). Conserving and reserving resources for the future generation and adhering to attain the goals for a better living standard are the focus of sustainable development. Dunphy, Griffiths \& Benn (2003) also identified sustainability as one of the most suitable avenues for organizations and corporations.

According to United Nations, 2016, "Sustainable development calls for concerted efforts towards building an inclusive, sustainable and resilient future for people and planet." Sustainable development stands on three spheres which encompass "economical, environmental and social" factors or "ecology, economy and equity" factors (United Nations, 2014). Some authors also add up a forth sphere named; institution or government. The three pillar or sphere model argued by Wilkson and Yencken (2000) is based on these factors.

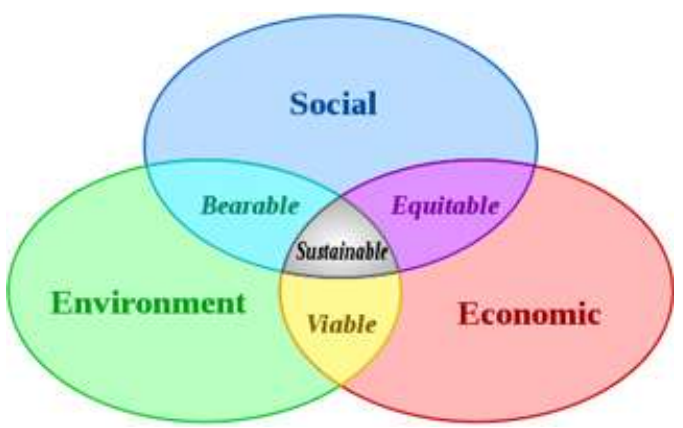

Figure 1: The three pillar or sphere model (Wilkson and Yencken, 2000)

Parkin (2000) has developed a five capital model based on natural, human, social, manufactured and financial assets. It is created on the concept of triple bottom line (TBL) which is being used to evaluate performance in a broader point of view to create greater business value (Slaper and Hall,2011).

Table 1: Five capital model (Parkin, 2000)

\begin{tabular}{|l|l|l|l|}
\hline $\begin{array}{l}\text { Sustainability Dimension } \\
\text { (i.e. Triple Bottom Line) }\end{array}$ & Type of Capital & Stock & Flow of Benefits \\
\hline 1. Environment & 1. Natural & $\begin{array}{l}\text { Soil, sea, air, wood, ecological } \\
\text { systems }\end{array}$ & $\begin{array}{l}\text { Energy, food, water, climate, waste } \\
\text { disposal }\end{array}$ \\
\hline \multirow{4}{*}{ 2. Social } & 2. Human & $\begin{array}{l}\text { Health, knowledge, } \\
\text { motivation, spiritual ease }\end{array}$ & $\begin{array}{l}\text { Energy, work, creativity, innovation, } \\
\text { love happiness }\end{array}$ \\
\cline { 2 - 4 } 3. Economy & 3. Social & $\begin{array}{l}\text { Governance systems, families, } \\
\text { communities, organizations }\end{array}$ & $\begin{array}{l}\text { Security, shared goods (e.g. culture, } \\
\text { education), inclusion }\end{array}$ \\
\hline & 4. Manufactured & $\begin{array}{l}\text { Existing tools, infrastructure, } \\
\text { buildings }\end{array}$ & $\begin{array}{l}\text { Living/work/leisure places, access, } \\
\text { material resources }\end{array}$ \\
\cline { 2 - 4 } & 5. Financial & Money, stocks, bonds & $\begin{array}{l}\text { Means of valuing, owning \& } \\
\text { exchanging the other four capitals }\end{array}$ \\
\hline
\end{tabular}

Kirby (2004) states that an "estimated 1 in 6 people suffer from hunger and malnutrition while attempts to grow food are hampering swathes of productive land". According to Oxfam International (2015), with one year, nearly half of the total wealth of the world will be concentrated on only $1 \%$ of the world's population. Approximately $80 \%$ of the population survives on only
$5.5 \%$ of the wealth. Thus profit-maximizing business and capitalism that are inflicting tension to the resources.

Financial sustainability was also a concern for the business. "Self-sustainable social business solutions are highly promising in three regards. First, if commercial viability is achieved, this relieves executives from fundraising and dependency on financial development 
"aid." Second, sufficient profits enable successful initiatives to be scaled up and replicated. Thirdly, social value creation - responding to poor or disadvantaged people's needs as the primary business driver - allows the social-minded entrepreneur take advantage of previously untapped business opportunities, entering new markets that are judged unprofitable or too risky for conventional businesses." (Humberg and Kleemann, 2014). According to Yunus (2007), social business is a cause-driven business process which will primarily focus to eliminate poverty from the society along with any one or more other objectives. Wee-Liang and Tan (2005) said: "social entrepreneurship focuses on the social impact that an endeavor carries."

"A social business borrows from both these entities. However, the social business is more cause-driven than profit-driven, with the potential to change the world." (Yunus, Moingeon, and Lehmann-Ortega, 2009)

A diagram is given below to enlighten the whole concept of social business in a nutshell.

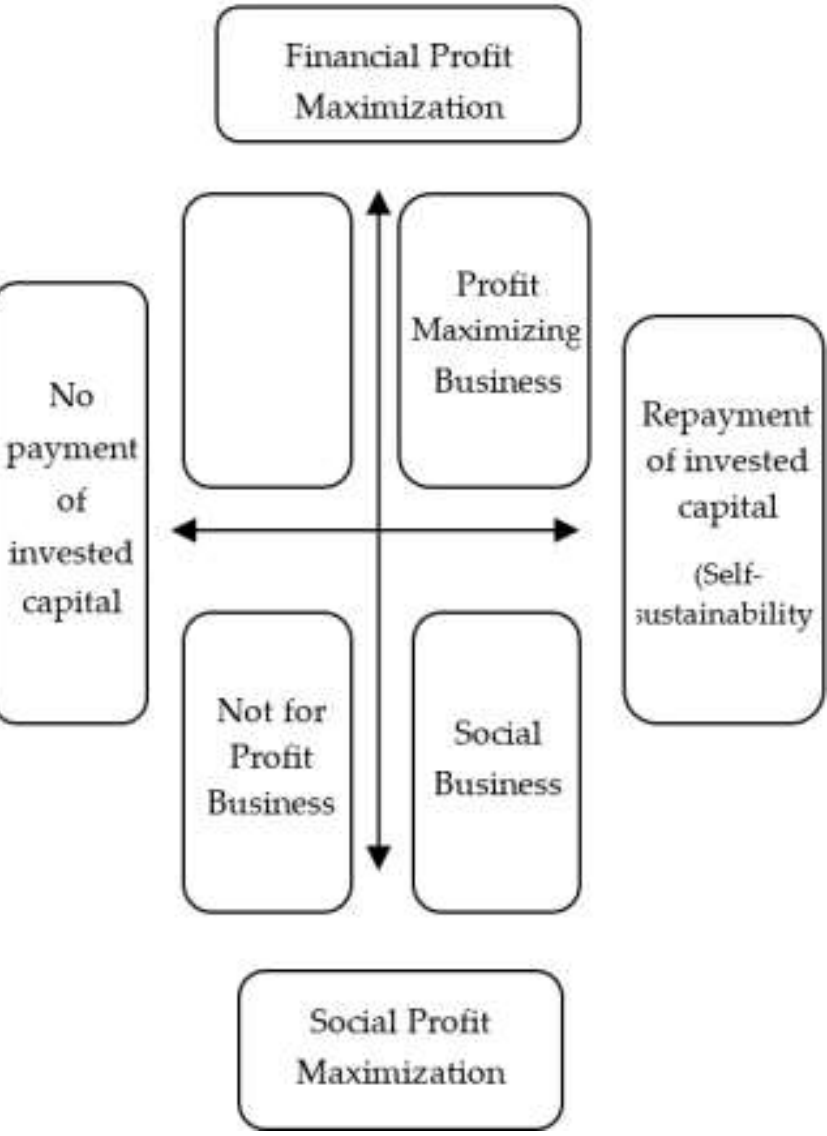

Figure 2: Social Business vs. profit-maximizing business and not for profit business (Yunus, Moingeon, and Lehmann-Ortega, 2009)

Grameen Bank, came up with a plan to work with a leader in the fresh dairy products in the French food industry, named Group Danone. Grameen Danone Food Limited (GDFL) is said to be the 'first purpose-built social business business' (Yunus and Weber, 2007). It works with the mission to "reduce poverty by a unique proximity business model working with daily healthy nutrition to the poor" (Grameen group \& Danone Asia Pte Ltd. 2006). "GDFL, a joint venture between Group Danone and Grameen Bank integrates the values of the requirements for a successful business and social concerns." (Ghalib, Hossain, and Arun, 2009). Grameen Danone's Memorandum of Understanding (MoU) shows that this is a business formulated to maximize social benefits rather than financial profits (Yunus, 2007). Grameen Danone focuses on alleviating malnutrition of the children by selling fortified yogurt at an affordable price. GrameenDanone invested in a small scale yogurt factory at Bogra, Bangladesh. . Humberg (2011) said, "In the long run, the company's victory should be measured not by the amount of profit generated, but by the number of children who avoid malnutrition each year."

\section{OBJECTIVE OF THE STUDY}

The idea is relatively new in Bangladesh as few organizations are claiming to be sustainable, without the proper understanding of sustainable development. This study will be focusing towards Sustainability of social business, particularly, Grameen Danone Foods Ltd. The objectives of this study are:

- To understand how to achieve sustainable development through social business.

- To realize the business features of Grameen Danone Foods Ltd.

- To evaluate the business and social goals of GDFL.

- To check whether GDFL can meet the sustainable development goals.

\section{Methodology}

Social business is a new approach undertaken by some sectors which will be beneficial to the country's further development. As Grameen Danone Foods Ltd. is one of the few social businesses in Bangladesh which follows sustainable development goals, a total of twelve officials, ten executives, and two Human Resource Managers have been interviewed. The response rate was $80 \%$. The research, conducted on convenience sampling with an open-ended questionnaire. Moreover, the author has made informal discussion with the professors of Economics and Business to understand the overall economic perspective of social business as a key to attaining sustainable development goals.

\section{SUSTAINABLE DEVELOPMENT THROUGH SOCIAL BUSINESS}

The world leaders have come up with seventeen sustainable development goals (SDGs) on 2015 as a pathway for the 2030 Agenda for Sustainable Development. "The SDGs build on the success of the Millennium Development Goals (MDGs) and aim 
to end all forms of poverty. The new Goals are unique which call for action by all countries, poor, rich and middle-income to promote prosperity while protecting the planet. Recognize that ending poverty must go handin-hand with strategies that build economic growth and addresses education, health, social protection, and job opportunities, while tackling climate change and environmental protection." United Nations (2016).

Organization for Economic Co-operation and Development (OECD) is an organization which promotes strategies that will improve the economic and social well-being of people (OECD, 2016). Public policies can create an enabling environment for social business if policy makers adopt a systemic vision of social business and fully understand the contribution that it can make to the improvement of economic and social development and well-being. The OECD has highlighted some important areas for national and local policy action in developed countries in cultural, legal, financial and social segments (OECD/European Union, 2013).

According to Yunus (2010),"social business offers an valuable way to solve problems and I would like to urge OECD countries to explore this path towards sustainable development, promoting the creation of social business funds by ventures, governments, foundations, and individuals". Social business has its own set of opportunities, limitations and risks. The entrepreneur has to tap the correct field to find out the benefit of the opportunities while minimizing the risk factors, just like any other business ventures. Humberg (2011) has focused on the ability of social business for being sustainable. Social business can:

- Convert poor communities from "aid" beneficiaries into active participants,

- Introduce short-term development programs into commercially viable business solutions.

- Create opportunities for experimentation, innovation, replication and growth

- Create avenues for cross-section collaboration for private and public sectors for social development

\section{Grameen Danone- A Social Business}

\section{The backdrop}

Grameen Danone's has established its first production plant in Betgari, Bogra City in Bogra District, about 140 miles northwest of Dhaka. A high rate of people lives under the poverty line over there. There are several "char" (small islands) areas which are flooded during the rainy season or whenever the water line of the Jamuna increases. "Seasonal declines in employment often lead to sustained loss of assets and income. Households without land usually have no substitute than to settle in areas highly exposed to flooding and acute land erosion." (Humberg, 2011). In places like these, survival becomes a tough job, and proper nutrition becomes a luxury. To tackle the situation, Yunus had come up with a plan create a social business that would create sustainability of the people of that area.

\section{The business model of Grameen Danone at a glace}

Formation: Grameen Danone's Memorandum of Understanding (MoU) demonstrates that the joint venture is designed to both optimize and maximize social benefits rather than financial profits (Grameen group and Danone Asia Pte Ltd. 2006; Yunus 2007). They inaugurated in 2006 as a private ltd. Company. Grameen Danone is a 50/50 joint venture between the Grameen Group and Group Danone where Group Danone was represented by Danone Asia Pte. Ltd (21\%) and Danone Communities (29\%). The Grameen group, represented by four subsidiaries, Grameen Business Promotion, Grameen Energy, Grameen Welfare and Grameen Telecom, each holding $12.5 \%$ share.

Mission Statement and Vision: The mission statement of this organization is social aspirations such as alleviation of malnutrition, reduction of poverty, etc. with practical business details which are the employment of a proximity business model, operation on a non-loss basis, pays back the capital.

The vision of this social business in to create up to 50 factories, that provide fresh and healthy dairy items to Bangladeshis by 2020.

Objectives: According to Humberg (2011), “Grameen Danone's joint venture agreement elaborates on three primary business objectives (Grameen group and Danone Asia Pte Ltd. 2006)

- Be a non-loss operation company; with no shareholder losing money in their participation.

- Be able to generate enough surpluses to pay back the invested capital to the parties as early as possible.

- Grameen Danone will pay a 1\% dividend annually to the shareholders. The remaining profits will be reinvested in the joint venture company."

According to Grameen group and Danone Asia Pte, Ltd.(2006) the joint venture's primary social objectives are as follows:

- Allow low-income, nutritionally deprived populations (especially children) to have access (regarding affordability and availability) to daily healthy nutrition to improve their nutritional condition.

- Poverty reduction is to improve the economic conditions of local suppliers (farmers) and helping them to improve their practices (upstream), involving the local population via a low-cost / labor-intensive manufacturing model (production), and contributing to the creation of jobs through the distribution model (downstream).

Key resources: The asset of Danone's technical knowhow of fortified yogurt production and marketing of dairy products was blended with the knowledge of Grameen's local market insight and socioeconomic connection throughout the country (Humberg, 2011). 
Key activities: Grameen Danone's scope of business covers the manufacturing, packaging, marketing, sales, and distribution of fermented fresh dairy products under the brand name Shakti+ (Humberg, 2011). These core activities are the linked to social marketing where the local mass is educated on nutritional benefits and the need for proper health care facilities. "A proximity-based model works to bring supply, production, retail, and consumption of a product as close to one another as possible." (Rodriques and Baker, 2012).

Business rationale: The business rationale was twofold, one, minimizing the up-front cost and investment risk and limiting the distribution area of the company's fresh dairy product, thus eliminating the need for long-distance shipping, refrigerated warehouses, and trucks (Yunus, 2007). The plant was designed in such a way and in such a concept that would create employment opportunities for the local unskilled and uneducated people.

\section{The Market Analysis}

The product: Shakti+ is the name of the product launched by GDFL, also known as Shakti Doi which means energy yogurt. Made of pure full cream cow milk which is collected from nearby villages, live fermenting cultures, sugar and data molasses. According to (Humberg, 2011), “a 60 gram cup covers $30 \%$ of children's daily requirements of vitamin A, zinc, iron, and iodine37, also a natural source of calcium and protein. Shakti Doi is supposed to develop the nutritional status of children aged 3 to 15 years, consumed on a regular base - at least one cup twice a week." There are 40grams, 60grams and 80 grams cups, found as plain yogurt, plain with extra protein, mango flavored and strawberry flavored.

Customer Segment: The consumers of Shokti Doi are primarily children living in the urban and rural area. The segmentation in shown below:

Table: 2 Customer segment of Shokti Doi (GDFL)

\begin{tabular}{|c|c|c|}
\hline \multirow{2}{*}{\multicolumn{2}{|c|}{$\begin{array}{l}\text { Classifications of } \\
\text { Customers } \\
\text { Rural buyers and } \\
\text { their parents }\end{array}$}} & Characteristics \\
\hline & & $\begin{array}{l}\text { - Live is remote and } \\
\text { dispersed settlements } \\
\text { - Short in purchasing powers } \\
\text { - Lack nutritional awareness }\end{array}$ \\
\hline \multirow[t]{3}{*}{$\begin{array}{l}\text { Urban } \\
\text { buyers } \\
\text { and } \\
\text { their } \\
\text { parents }\end{array}$} & $\begin{array}{l}\text { Lower } \\
\text { Class }\end{array}$ & $\begin{array}{l}\text { - Living in smaller cities } \\
\text { - Little purchasing powers } \\
\text { - Little knowledge } \\
\text { nutrition of } \\
\text { - Product accessible through } \\
\text { corner stores }\end{array}$ \\
\hline & $\begin{array}{l}\text { Middle } \\
\text { and } \\
\text { upper- } \\
\text { class }\end{array}$ & $\begin{array}{l}\text { - Sufficient buying power } \\
\text { - General health awareness } \\
\text { - Accessible through super } \\
\text { shops and corner stores }\end{array}$ \\
\hline & $\begin{array}{l}\text { Slum } \\
\text { dwellers }\end{array}$ & $\begin{array}{l}\text { - Little purchasing power } \\
\text { - Little nutrition awareness } \\
\text { - Accessible through door-to- } \\
\text { door sales }\end{array}$ \\
\hline
\end{tabular}

Distribution model: The distribution of Shakti Doi works on two models; one is Shops another one is Door-to-door sales. Shops represent $75 \%$ of the current Grameen Danone sales (Danone communities, 2012). According to Danone Communities (2012), "in rural areas through a network of sales ladies work for the door to door sales. These "Grameen Danone ladies" are microentrepreneurs. They are supplied with yogurts, trained and coached by Grameen Danone staff. They get one-day sales credit, compensate the cost of cups through their sales and keep profit on each sold cup. During 2012, number of ladies exceeded 580. Door-to-door sales through ladies are $25 \%$ of Grameen Danone sales."

Distribution channel: In the rural areas marketing strategies such as leaflet distribution, rickshaw announcements, encouraging social leaders to convey the message, "mini-events", etc. processes are followed. Zinedine Zidane, a world renowned football player, came to Bangladesh to promote Shokti Doi in 2006 (Grameeninfo, 2007). To attract the urban as well as rural market GDFL made an advertisement with the Bangladeshi cricket sensation Shakib Al Hasan (Danone communities, 2013).

Table 3: Grameen Danone's distribution channel (Humberg 2011)

\begin{tabular}{|c|c|}
\hline Channel & Area \\
\hline $\begin{array}{l}\text { Door-to-door sales through own rural } \\
\text { sales network, comprising two sales } \\
\text { supervisors, around } 33 \text { sales assistants, } \\
175 \text { sales ladies working on regular base }\end{array}$ & $\begin{array}{l}\text { Bogra, } \\
\text { Shirajgonj } \\
\text { and } \\
\text { Rajshahi } \\
\text { District }\end{array}$ \\
\hline $\begin{array}{lll}\text { Door-to-door sales through } & \text { CARE's } \\
\text { Rural sales program } & & \\
\end{array}$ & $\begin{array}{l}\text { Rangpur } \\
\text { District }\end{array}$ \\
\hline Door-to-door sales through 25 sales ladies & $\begin{array}{l}\text { Dhaka } \\
\text { District }\end{array}$ \\
\hline $\begin{array}{l}\text { Sales through more than } 1600 \text { small retail } \\
\text { shops (including } 396 \text { rural stores) }\end{array}$ & $\begin{array}{l}\text { Bogra, } \\
\text { Chittagon } \\
\text { g, Sylhet, } \\
\text { Khulna, } \\
\text { Dhaka }\end{array}$ \\
\hline $\begin{array}{l}\text { Sales through } 50 \text { modern trade shops } \\
\text { (appr. } 90 \% \text { coverage) }\end{array}$ & Dhaka \\
\hline
\end{tabular}

Competition: Misty Doi (sweet yogurt) from Bogra is a renowned treat for the Bangladeshis. Though Shokti Doi and Misty Doi both are yogurts with little similarities are seen regarding texture, taste, appearance, color, price, smell, and packaging. So these two products are not direct competitors. Indirect competitors such as packaged drinks, snacks, biscuits, chips from several companies take away a share of the parents' budget for the children's snacking, which may leave little room for the purchase of a nutritious product, Shokti Doi. 


\section{Analyzing Grameen Danone}

\section{Analyzing the Business Objectives}

Maurel (2009) in his paper said: "Become profitable to ensure economic sustainability." Though GDFL is a social business, financial measurement is not a criterion for its success, but measuring the economic situation of the organization will enable the author to understand its situation in the market. From Grameen Group and Danone Asia Pte. Ltd. (2006), it was found that one of their business objectives is to "after the capital amount is paid back, Grameen Danone will pay a 1\% dividend annually to the shareholders. The remaining profits will be reinvested in the joint venture company." This objective deviates from the basic concept of social business of "nonprofit, non-divided" policy.

Reinvestment of remaining profits in the joint venture is still not full-filled as this venture is still in the loss-making process (Grameen Group and Danone Asia Pte. Ltd.2010). According to Humberg (2011), "neither Grameen nor Danone executives currently have the heart to forecast when exactly their company might have generated enough surplus to pay back the initial investment."

The joint venture of one dairy giant and the other is a successful collaboration of banks and other institutes was nearly failing for several reasons.

Unrealistic business plan: After the joint venture established GDFL assumed to produce the product at Taka 2.5, provide sales commission of Taka 0.6 and sale at Taka 5 per 80 grams of a cup. But these assumptions were unrealistic as the sufficient demand to be able to produce and sell a cup of yogurt at Taka 5 was over estimated. After that GDFL reduced the cup size from 80grams to 60 grams but the target market at Bogra also turned out to be lower than the estimation. Danone Communities, (2012), said "Danone had never set up a business anywhere in such a short time" which left Danone in a shock wave. The Head of Danone Communities recollects, "We were targeting the most challenging consumer with the cheapest price we ever had- and we came in partnership with Grameen, but the overall mindset was 'Let's not talk about it too much. Let's start.' " They were simply in a hurry.

Governance issues: In the initial stage GDFL were solely focusing on the product and the purchasing capacity of the targeted market without thinking about the process to run the social business. For this reason, they were operating without a full-time manager and a complete marketing strategy for several months. Yunus (2010), said that when the business collapsed in 2008 and the company was accumulating losses per cup, there was a debate raging from Paris to Dhaka. Danone India came over to revive the business of GDFL which regarding of the employees of GFDL felt like a "take over".
Less demand for the product: The target customer of Shokti Doi is illiterate people living in the rural areas, lacking the knowledge of nutritional benefits. Also, their difficult financial situation toughens a weekly allowance for yogurt consumption. Many customers did not like the taste and smell of the Shokti Doi as it is different from the Misty Doi people are accustomed to eat.

Problems with infrastructure: Load shedding and power cuts are a regular problem in Bangladesh. No cold storage facilities and refrigeration facilities are there too. As these products are highly perishable, the sales ladies had to sell a product within 72 hours of receiving the product which was sometimes impossible to meet.

Socio-cultural barriers: The traditional socio-cultural system of Bangladesh does not support women going from door-to-door, all alone; selling stuffs (Humberg, (2011). Women in rural areas try to be close to their neighboring which restricts their mobility. They also feel shy to talk to strangers especially, male.

High operation cost: Initially the operation cost of the office, administration, sales and promotional activities got higher than the assumption as the sales rate was very low, and after the economic crisis of 2008 if got worse. Rising price of raw materials, resource wastage, and high logistics costs per unit in rural sales were reasons for high direct cost (Humberg, 2011).

Increasing cost of raw material: After the global economic and financial crisis the costs of raw materials such as milk got almost doubled, Taka 14 (February, 2007) to Taka 26 (April, 2008). Price of sugar, data molasses, packaging costs also increased, ultimately increasing the price of 80 gram serving of yogurt from Taka 5 to Taka 8. This resulted in losing $80 \%$ of target market (Yunus, 2010).

Highly perishable product design: Yogurt, a dairy product has limited shelf life. Lack of refrigeration facilities in rural areas shortened the shelf life further. So the sales ladies had to sell the products within 72 hours of procuring.

Unfavorable product design: A non-biodegradable plastic cup took $15 \%$ of the total production cost. Moreover, no spoons were supplied until a second cup was purchased. The rural children often consumed the product with their bare dirty, unwashed hand or bamboo sticks which raised hygiene issues.

\section{Analyzing the social objectives}

Nutrition for children: The yogurt contains all the micronutrients required for the proper development of the children, but the impact is dependent upon the regularity of consumption. Global Alliance for Improved Nutrition (GAIN) conducted a research on the impact of Shakti doi on children if fed 4-5 times a week. But the consumption rate is unrealistic for rural mass. 
Consumption rate in Bogra: Though GDFL was established to eliminate the malnutrition of Betgari, Bogra, and to sell yogurt within $30 \mathrm{~km}$ of the factory, they had to shift their focus on urban sales as the customer base in rural area was very small. Big cities like Dhaka, Chittagong, and Sylhet showed them some positive sales points.

Job opportunities: GDFL was successful in creating job opportunities in Betgari, Bogra in the forms of Micro farmers, Sales ladies, distributors, farmers.

Micro farmer: The proximity model of GDFL was depended upon the micro farmers of Betgari, Nodadari and Shariakandi. From these farmers raw cow milk was collected twice a day on cash basis without the hassles of having any middle man in between thus reducing the chance of leftover milks. Also, farmers were encouraged to meet local veterinary doctors for proper care of cows.

Local employees: They employed semi-skilled and skilled people for positions such as working administration, facilitator, maintenance, quality control etc. positions. Several indirect job opportunities were also created.

Sales ladies: For the distribution channel GDFL was dependent upon the sales ladies who went from the door-to-door to supply the yogurt. Receiving commission on cups sold encouraged them to expand their sales base however any cups unsold had to be returned to GDFL that day. Social barriers and physical constrains were their constant struggles. Even, customers regularly bargain with them to reduce the price or give the product to them as charity. However, the ladies are highly motivated to continue as they receive cash to survive their daily lives.

\section{Grameen Danone- A Success Story or Not}

After the analysis of GDFL in the context of business and social objectives, several points have raised whether GDFL is a success story of a sustainable social business or not. Here, we can compare Grameen Danone with the seventeen sustainable development goals set by United Nations.

Table 4: Comparing the outcomes of Grameen Danone business with the Sustainable Development Goals

\begin{tabular}{|l|l|}
\hline Goal & Situation of GDFL \\
\hline $\begin{array}{l}\text { Ensuring healthy } \\
\text { lives and nutrition } \\
\text { for all at all ages }\end{array}$ & $\begin{array}{l}\text { Ensuring nutrition in the malnourished } \\
\text { children in poverty stricken Bogra is one } \\
\text { of the objectives of GDFL, but they are } \\
\text { yet to prove any scientific report on } \\
\text { consumer's improved nutritional status. }\end{array}$ \\
\cline { 2 - 3 } & $\begin{array}{l}\text { Offering nutrition through a cup of yogurt } \\
\text { was at a question as they had to reduce the } \\
\text { serving portion per cup size thus the } \\
\text { supplied nutrition per cup also reduced. }\end{array}$ \\
\hline $\begin{array}{l}\text { Ensuring } \\
\text { economic growth } \\
\text { by employment } \\
\text { and decent work } \\
\text { (Developing rural } \\
\text { lives) }\end{array}$ & $\begin{array}{l}\text { Creating job opportunity using the } \\
\text { proximity model was a success to some } \\
\text { extant as GDFL has employed locals people } \\
\text { of Bogra as suppliers of raw material, micro } \\
\text { entrepreneurs, and sales ladies. }\end{array}$ \\
\cline { 2 - 3 } & $\begin{array}{l}\text { The primary objective of GDFL was to } \\
\text { excel the business in Bogra's rural areas }\end{array}$ \\
\hline
\end{tabular}

\begin{tabular}{|c|c|}
\hline & $\begin{array}{l}\text { but to survive as a business organization } \\
\text { they had to shift their focus in urban areas. }\end{array}$ \\
\hline $\begin{array}{l}\text { Ending poverty in } \\
\text { all forms, } \\
\text { everywhere }\end{array}$ & $\begin{array}{l}\text { Though GDFL does not help the micro } \\
\text { farmers, sales ladies, and consumers to } \\
\text { move out of poverty, it surely helps } \\
\text { them to survive. }\end{array}$ \\
\hline \multirow[t]{2}{*}{$\begin{array}{l}\text { Achieving gender } \\
\text { equality }\end{array}$} & $\begin{array}{l}\text { Creating employment opportunity for } \\
\text { women as sales ladies who are living } \\
\text { poor or extremely poor lives. But this } \\
\text { scale is very low. }\end{array}$ \\
\hline & $\begin{array}{l}\text { Many sales ladies admit that they are only } \\
\text { working as sales ladies as they do not have } \\
\text { any other option. This job is challenging in } \\
\text { both physical and social perspective. }\end{array}$ \\
\hline \multirow[t]{2}{*}{$\begin{array}{l}\text { Promoting } \\
\text { sustainable } \\
\text { industrialization } \\
\text { and fostering } \\
\text { innovation }\end{array}$} & $\begin{array}{l}\text { GDFL built its plant in a rural area } \\
\text { where people lived in extremely poor } \\
\text { conditions so that they can develop the } \\
\text { overall industrialization of that locality. } \\
\text { However, cold stores are still } \\
\text { unavailable, and supply of electricity is } \\
\text { scarce in the rural area. }\end{array}$ \\
\hline & $\begin{array}{l}\text { Financial sustainability of GDFL is at a } \\
\text { question as it has only touched the } \\
\text { break-even point recently. It took seven } \\
\text { long years to come at this point and } \\
\text { which is mainly because of urban sales } \\
\text { (not an objective of this social business). }\end{array}$ \\
\hline Ensuring hygiene & $\begin{array}{l}\text { GDFL ensures proper hygiene in the } \\
\text { production of this fortified yogurt, but } \\
\text { they did not focus on the consumption } \\
\text { process which created some hygiene } \\
\text { issues as they did not supply spoons thus } \\
\text { children used their unwashed hand and } \\
\text { bamboo sticks to consume the yogurt. }\end{array}$ \\
\hline
\end{tabular}

Source: Own draft based on analysis

\section{Conclusion}

Garrette and Karnani (2001) have said that startup companies tend to be too optimistic about their revenue to be generated, not taking into account the time the consumers need to learn about the new business and even more time for them to change their buying habits or become a regular customer. It is exactly the case of Grameen-Danone Foods Limited. As fortified yogurt for the nutritional benefit of the children living in rural areas was a previously untapped market, they did not give it enough time to gather the minimum knowledge to predict the situation. This innovative and appropriate business venture was suffered by the lack of knowledge about target consumers purchase ability, their taste, and preferences, financial and infrastructural resources. The rural customers are from poor or extremely poor families, unable to buy the minimum quantity of Shokti Doi each week is nearly impossible; they are also extremely price sensitive. Again, their taste and preference for such a new product required them to teach the target customers. As this a "no-profit, no-dividend" business, it required the parent companies to donate. As they were unable to make any profit they could not return any investment amount to the parent organizations. The smoothness of the venture still depends 
on donations from the do-gooders thus it remains in the "category of charity" (Yunus 2007). This is contradictory of the concept of social business. Only recently GDFL has come to the break-even point, but this is only because of the urban sales in cities like Dhaka, Chittagong, and Sylhet. To accomplish social and financial sustainability GDFL has to fulfill three targets, illustrated by Humberg, (2011). These are: to make the business commercially viable being in the boundaries of social business, to allow high rural invasion though increasing affordability, to improve the nutritional benefit per cup size and to encourage replication if it becomes a success story in other sectors of Bangladeshi industries and in several Asian countries with similar financial and social conditions.

\section{REFERENCES}

Butlin, J 1989, 'Our common future. By World commission on environment and development.' Journal of International Development vol.1 no.2 pp. 284-287. Available from: doi:10.1002/jid.3380010208 ISSN 1099-1328 [20 $20^{\text {th }}$ March 2016]

Danone Communities 2012, Danone Sustainability Report. Available from: http://danone.at/wpcontent/uploads/2014/04/Danone_Sustainability_Report_201 2.pdf [28th February 2016]

Danone Communities 2013, Danone Sustainability Report. Available from: http://www.danonecommunities.com/sites/default/files/pr esentation_projet_grameen_danone_food_ltd_feb_2013.pdf [1st March 2016]

Dunphy, D, Griffiths, A, \& Benn, S 2003, The Drivers of Change: Organizational change for corporate sustainability' Routledge, London.

Garrett, B, \& Karnani, A 2010, 'Challenges in marketing socially useful goods to the poor.' California Management Review vol, 52, no.4, pp. 29-47.

Ghalib, A, Hossain, F, and Arun, T 2009, 'Social Responsibility, Business Strategy and Development'. The Australasian Accounting Business \& Finance Journal, Responsibility, Business Strategy and Development. Vol.3, No. 4

Grameen Info 2007, 'Zidane Inaugurates first Grameen Danone Dairy Plant' Available from http://www.grameen-info.org/zidaneinaugurates-first-grameen-danone-dairy-plant/ [15 ${ }^{\text {th }}$ March 2016]

Humberg, K \& Kleemann, L 2014, 'Enhancing the Contribution of Social Business to Sustainable Development' Development Cooperation Report, Mobilizing Resources for Sustainable Development pp.187-196

Humberg, K 2011, 'Poverty Reduction through Social Business? Lessons Learnt from Grameen Joint Ventures in Bangladesh' Oekom Verlog pp. 1-14

Khan, S 2015, 'The Champion of Poverty Alleviation.' Prothom Alo. Available from http://en.prothomalo.com/opinion/news/70709/The-champion-of-povertyalleviation, [28 $8^{\text {th }}$ June 2015] pp. 11

Kirby, A 2004, 'Introduction: Planet under pressure.' Available from: http://news.bbc.co.uk/2/hi/science/nature/3686106.stm [21st February, 2016]

Leopold, A 1949, 'A Sand County Almanac', Oxford University Press. United States of America. pp. 31

Maurel, O 2009, 'Grameen-Danone Foods Ltd: Overview.' Available from http:/ / www.slideshare.net/danonecommunities/grameendanone-food-ltd-overview-210609. [3rd January 2011].
OECD/European Union 2013, 'Policy Brief on Social Entrepreneurship' Publication Office of the European Union, Luxembourg, Available from: www.oecd.org/cfe/leed/Social\%20entrepreneurship\%20policy\%20bri ef\%20EN_FINAL.pdf [13 ${ }^{\text {th }}$ March, 2016]

Organization for Economic Co-operation and Development 2000, 'Social Enterprises,' OECD Publishing, Paris, Available from http://dx.doi.org/10.1787/9789264182332-en [15th March 2016]

Oxfam International 2015, 'Richest 1\% will own more than all the rest by 2016' Available from: https:/ /www.oxfam.org/en/pressroom/pressreleases/2015-0119/richest-1-will-own-more-all-rest-2016 [1 ${ }^{\text {st }}$ June 2015]

Park, P 2015, 'Interview with Muhammad Yunus' Available from http:/ / www.alliancemagazine.org/interview/interview-withmuhammad-yunus/ [11 ${ }^{\text {th }}$ March 2016] pp. 27-29

Parkin, S 2000, 'Sustainable Development: The Concept and the Practical Challenge.' Proceedings of the Institution of Civil Engineers, Civil Engineering, vol.138, pp. 3-8.

Rodrigues, J \& Baker, GA 2012, 'Grameen-Danone Foods Limited (GDF)' International Food and Agribusiness Management Review , vol.15, no.1, pp. 127-158

Slaper, T F \& Hall, TJ 2011, 'The Triple Bottom Line: What Is It and How Does It Work?' Indiana Business Review. vol. 86, no. 1.

Sowell, T 2003, 'Profit Motive Underrated By Intelligentsia.' Sunsentinel. Available from: http:/ /articles.sun-sentinel.com/200312-26/news/0312241220_1_profits-million-dollars-costs $\quad\left[19^{\text {th }}\right.$ March 2016]

Sullivan, A \& Steven M S 2003, 'Economics: Principles in action.' Upper Saddle River, New Jersey 07458: Pearson Prentice Hall. p. 29.ISBN 0-13-063085-3.

Sustainable Development Goals 2016, 'The Sustainable Development Agenda' Available from http:/ / www.un.org/sustainabledevelopment/developmentagend [11th March 2016]

United Nations 2014, 'Prototype Global Sustainable Development Report' United Nations Department of Economic and Social Affairs, Division for Sustainable Development. Available from https://sustainabledevelopment.un.org/globalsdreport/2014 [12th March 2016]

Wee-Liang, WJ \& Tan, T 2005, and 'Defining the 'Social' in Social Entrepreneurship': Altruism and Entrepreneurship.' International Entrepreneurship and Management Journal. Vol.3 pp. 353-365.

Wilkinson, D \& Yencken, D 2000, 'Resetting the Compass: Australia's Journey Towards Sustainability.' Collingwood, VIC: CSIRO Publishing. Available from http://samples.sainsburysebooks.co.uk/9780643091733_samp le_295425.pdf [11th March 2016]

Yunus, M \&Weber, K 2007, 'Creating a World without Poverty, Social Business and the Future of Capitalism'. New York: Public Affairs (Perseus).

Yunus, M2007, 'Creating a World without poverty' New York, Public Affairs

Yunus, M 2010, 'Building Social Business - The New Kind of Capitalism That Serves Humanity's Most Pressing Needs' Public Affairs, New York.

Yunus, M, Moingeon, B, \& Lehmann-ortega, L 2009, 'Building Social Business Models: Lessons from the Grameen Experience.' HES Paris

$$
--0--
$$

